\title{
Growth and Productivity of Irrigated Coffee Trees (Coffea arabica) in Ceres-Goiás
}

\author{
Eloisa Aparecida da Silva Ávila ${ }^{1}$, Cleiton Mateus Sousa ${ }^{1}$, Welington Pereira ${ }^{2}$, Vinícius Gonçalves Almeida ${ }^{1}$, \\ Jefferson Kran Sarti $^{1} \&$ Daniel Pereira da Silva ${ }^{1}$ \\ ${ }^{1}$ Instituto Federal Goiano, Campus Ceres, Ceres, GO, Brazil \\ ${ }^{2}$ Ministério da Agricultura, Empresa Brasileira de Pesquisa Agropecuária, Pecuária e Abastecimento, Brasília, \\ DF, Brazil \\ Correspondence: Eloisa Aparecida da Silva Ávila, Instituto Federal Goiano, Campus Ceres, Caixa Postal 51, \\ Rodovia GO 154, Km 03, s/n, Zona Rural, CEP: 76.300-000, Ceres, GO, Brazil. Tel: 62-98457-3458. E-mail: \\ eloisaavila190@gmail.com
}

Received: July 3, 2019

doi:10.5539/jas.v12n2p138
Accepted: December 17, 2019 Online Published: January 15, 2020

URL: https://doi.org/10.5539/jas.v12n2p138

\begin{abstract}
The objective of this work was to evaluate the growth and productivity of cultivars and progenies of arabica coffee under irrigation by driping in Ceres-Goiás. It was conducted in the experimental area of the Goiano Federal Institute-Ceres Campus. A total of 35 treatments were randomized blocks with four replications, from January 2017 to August 2018. At 30 and 36 months after planting, the diameter of the orthotropic branch, canopy diameter, plant height, number of nodes in the plagiotropic branch 1 , length of the plagiotropic branch 1 , number of nodes in the plagiotropic branch 2, length of the plagiotropic branch 2, length of the plagiotropic branches 1 and 2, number of nodes of the plagiotropic branches 1 and 2 and productivity were evaluated in 2018. The linear simple correlations were estimated in all evaluated characteristics. There was a difference in growth and yield of the evaluated genotypes. There is a positive correlation among the vegetative characters and the productivity. Catucaí Amarelo 2SL presented higher growth than the other evaluated genotypes. The genotypes Catiguá MG 1, Acauã Novo, Acauã 2 and 8, Catucaí Amarelo 24/137, Catucaí Amarelo 2SL, Asa Branca, Paraíso H419-10-6-2-10-1, Catuaí Vermelho IAC 15, Acauã, Sarchimor MG 8840, IPR 98, Araponga MG 1 and Obatã Vermelho IAC 1669-20 were the ones that had the highest productivity.
\end{abstract}

Keywords: production, genotypes, vegetative characters, irrigation

\section{Introduction}

The coffee tree originates in Africa, from regions where there is an extensive period of drought. This fact led several species of this plant genus to develop an adaptation to different edaphoclimatic conditions (Aerts et al., 2017; Herrera \& Lambot, 2017). Due to its high demand and economic relevance, it is therefore necessary to find genetic material that adapts to different regions and presents higher productivity.

The custom of drinking coffee was given by the Arabs (Aerts et al., 2017). Currently, it is considered the most consumed beverage in the world, Brazil being the second largest consumer, losing only to the United States (CECAFÉ, 2018). Its importance in the world agricultural scenario is due not only to the economic bias, but also to political and socio-cultural aspects (Aerts et al., 2017).

In 2018, there was a record in coffee exports, but this growth was already accelerating since 2012 (ICO, 2018a). In Brazilian agribusiness, production in the 2017-2018 crop year was 51 million bags of coffee and this represents $31.9 \%$ of world production, followed by Vietnam, 18.5\% and Colombia, 8.8\% (ICO, 2018b).

Commercial coffee began to be produced also in the Cerrado and its expansion occurred because production can be favored by aspects such as topography and temperature, combined with irrigation, fertilization and production technologies (Krohling et al., 2017). Goiás is in the eighth position in the national ranking, where 195.4 thousand sacks, exclusively of the Arabica type, were produced that year under irrigation regime (CONAB, 2018).

The increase in night minimum temperatures has been a factor that has affected the production of coffee, in the last harvests, in several places like Tanzania, Colombia, India and Southeast Africa (Krohling et al., 2017). Producers of coffee from around the world are looking for solutions to optimize production, lower costs, and 
worry about sustainability, through partnerships between scientists and cooperatives, both governmental and nongovernmental, focusing on training and search for new research and modern production techniques (Lambot et al., 2017).

Comparing the vegetative characteristics with productivity is an important method to study the adaptation of genotypes, observing their performance in a certain region (Rodrigues et al., 2012). The main criterion of selection in coffee is productivity and, for the recommendation of cultivars, it is essential to observe the interaction of the genotype with the environment (Krohling et al., 2017). Genetic variability is a determinant of the differences between coffees (Kitzberger et al., 2014). The genetic divergence among Arabic coffee cultivars can be decisive in the adaptation to the edaphoclimatic conditions of the environment, some being more resistant to pests, diseases, abiotic factors, water deficit, among others.

The evaluation of the cultivar architecture during its development cycle allows the selection of those that are more resistant and, at the same time, more productive. Productivity is one of the most important variables, especially when irrigation is used (Vicente et al., 2015). Studies on the architecture of the coffee tree have collaborated very effectively with the breeding programs, in the recommendation of new cultivars through the selection and validation of coffee progenies (Castanheira et al., 2016). The identification of cultivars with greater tolerance to different edaphoclimatic conditions becomes an essential factor for the growth of the national coffee industry. The objective of this study was to evaluate the growth and productivity of cultivars and progenies of arabica coffee with drip irrigation under Ceres - Goiás soil and climatic conditions.

\section{Material and Methods}

The experiment was implemented in April 2015, but this study was conducted from March 2017 to October 2018 , at the Goiano Federal Institute-Campus Ceres, located in the mesoregion of the Centro Goiano, in the city of Ceres-GO. For the evaluations of this work, the data of the second production cycle, that is, of the 2017/2018 harvest, were considered. The municipality of Ceres is located in the Valley of São Patrício, has the geographical coordinates and edaphoclimatic conditions, respectively: South latitude 15 $21^{\prime} 00.67^{\prime \prime}$, West longitude: $49^{\circ} 35^{\prime} 56.98^{\prime \prime}$, approximate altitude of $570 \mathrm{~m}$.

The climate of the region, according to the classification of Köppen, is Aw type, warm and semi-humid with well defined season, from May to September, with average annual temperature of $27.7{ }^{\circ} \mathrm{C}$, with minimum and maximum averages of 19.0 and $36.4{ }^{\circ} \mathrm{C}$, respectively. The average annual rainfall is about $1,601 \mathrm{~mm}$. The relief is gentle. The soil is characterized as Red Latosol (Santos et al., 2013).

For chemical characterization of the soil, samples were collected about two months before the experiment was installed. The chemical and physical properties of the soil in the experimental area are: $37.7 \%$ sand, $8.3 \%$ silt and $54.0 \%$ clay; $\mathrm{pH}$ (in water) = 5.80; M.O. $=20.30 \mathrm{~g} \mathrm{dm}^{-3}$ (colorimetric); $\mathrm{P}=12.8 \mathrm{mg} \mathrm{dm}^{-3} ; \mathrm{K}=0.2 \mathrm{cmol} \mathrm{dm}^{-3}$; $\mathrm{Ca}=3.0$ cmolc dm${ }^{-3} ; \mathrm{Mg}=1.80 \mathrm{cmolc} \mathrm{dm}^{-3} ; \mathrm{H}+\mathrm{Al}=2.70 \mathrm{cmolc} \mathrm{dm}^{-3}(\mathrm{SMP}$ buffer at $\mathrm{pH} 7.5) ;$ and $\mathrm{V}=65.7 \%$. The methodology used for all soil analyzes followed the recommendations of Embrapa (2013) and were done at the Soil Laboratory of the Goiano IF-Ceres Campus.

The fertilization was done according to the recommendation of the 5th modified approach of the Soil Fertility Commission of the State of Minas Gerais (Guimarães et al., 1999) and based on the results of the soil analysis.

Nitrogen (ammonium sulphate) and potassium (potassium chloride) applications were carried out in 3 plots on $09 / 22 / 2017,06 / 10 / 2017$ and 10/20/2017. On the other hand, phosphate fertilization (single super phosphate) was carried out, in a single application, on $02 / 09 / 2017.130 \mathrm{~kg} / \mathrm{ha}$ of $\mathrm{N}, 150 \mathrm{~kg} / \mathrm{ha}$ of $\mathrm{P}_{2} \mathrm{O}_{5}$ and $100 \mathrm{~kg} / \mathrm{ha}$ of $\mathrm{K}_{2} \mathrm{O}$ were applied.

Pest and disease control was done by means of constant monitoring, according to the need of the crop. In the interlining of the coffee plantation, Brachiaria (Urochloa decumbens) was planted with the purpose of favoring the chemical and physical-water attributes of the soil, optimizing its structure and increasing the water storage capacity (Rocha et al., 2016). The weeds were controlled along the planting line, brushing when necessary. Phytosanitary control was performed according to the need of the crop, in an equal manner, in all treatments.

The experiment was conducted in a randomized complete block design (DBC), with 35 genotypes (treatments) and four replicates. Each plot was composed of ten plants, whose spacing was $3.50 \times 0.75$ meters, constituting an area of $26.25 \mathrm{~m}^{2}$ per plot, totaling an experimental area of $3,675 \mathrm{~m}^{2}$ with 1,400 plants. As a useful part, eight central plants of the plot line were considered, totaling an area of $21 \mathrm{~m}^{2}$.

Thirty-one cultivars (Oeiras MG 6851 (EPAMIG), Catiguá MG 1 (EPAMIG), Sacramento MG 1 (EPAMIG), Catiguá MG 2 (EPAMIG), Araponga MG 1 (EPAMIG), Paraiso MG 419-1), Pau Brazil MG 1 (EPAMIG), Catiguá MG 3 (EPAMIG), Topaz MG 1190 (EPAMIG), IPR 104 (IAPAR), Sarchimor MG 8840 (EPAMIG), 
Catucaí Vermelho 20/15 cova 476 (PROCAFÉ), Tupi IAC (IAC), IPR 98 (IAPAR), IPR 99 (IPA 99), IPA 99 (IAC), Obatã Vermelho IAC 1669-20 (IAC), Obatã Amarelo IAC 4932 (IAC), Catuaí Vermelho IAC 15 (IAC), Catuaí Amarelo IAC 062 (PROCAFÉ), Catucaí Amarelo 24/137 (PROCAFÉ), Catucaí Amarelo 20/15 cova 479 (PROCAFÉ), Catucaí Vermelho 785/15 (PROCAFÉ), Catucaí Amarelo 2SL (PROCAFÉ) (PROCAFÉ), Asca Branca (PROCAFÉ), IBC-Palma 2 (PROCAFÉ), Acauã (PROCAFÉ), Acauã Novo (PROCAFÉ), and four advanced progenies [23]. II (EPAMIG), H-419-3-3-7-16-4-1 (EPAMIG), Paradise H 419-10-6-2-12-1 (EPAMIG), Paradise H 419-10-6-2-10-1 (EPAMIG)], all of the Coffea arabica species. The choice of these genotypes occurred because they were low in size, more resistant to rust and to the miner.

The irrigation was of the drip-type type, consisting of simple $16 \mathrm{~mm}$ polyethylene lateral lines and self-compensating emitters, with a flow of $2.2 \mathrm{~L} \mathrm{~h}^{-1}$, spaced $0.5 \mathrm{~m}$ apart. Irrigations were carried out in three irrigation shifts: Monday, Wednesday and Friday, according to ETc of the accumulated crop of the previous non-irrigated days. The applied blade was the same for all plots and calculated as a function of the accumulated reference evapotranspiration (ETo) of the Class A tank, located in the meteorological station of the institute itself. The blades are shown in Figure 1.

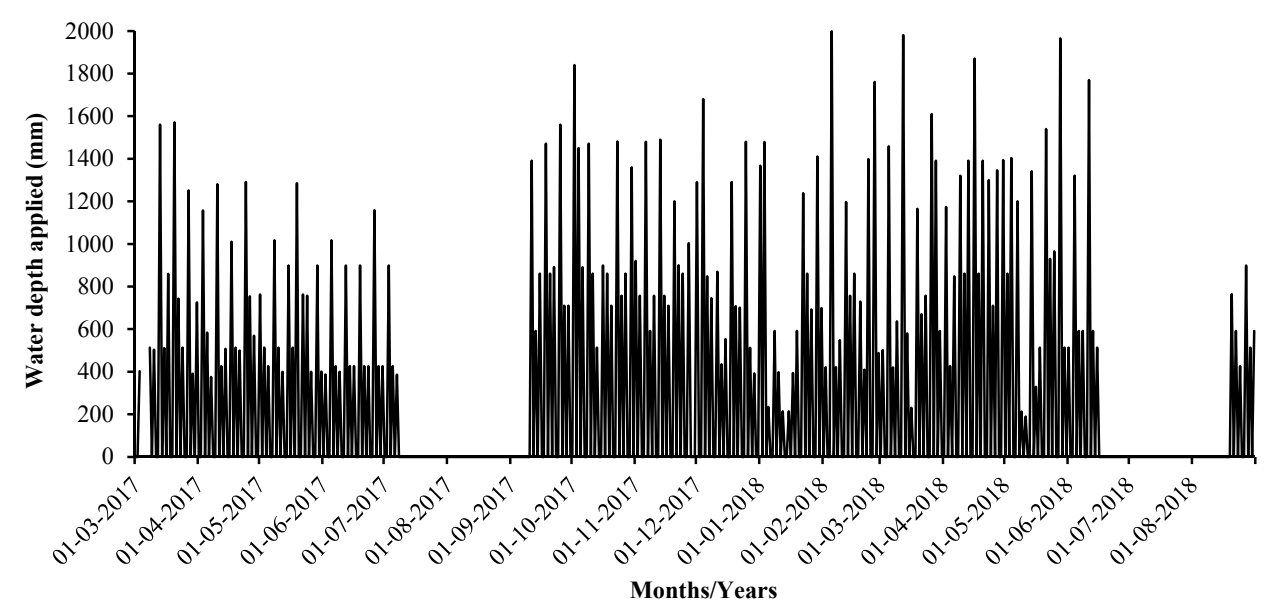

Figure 1. Water depth applied in the experiment

Note. Water depth applied in the experiment from March 2017 to August 2018.

In order to standardize flowering, controlled water stress management was adopted, suspending irrigation between 10/07/2017 to 11/09/2017 (62 days) and 18/06/2018 to 20/08/2018 (63 days) (Guerra et al., 2005).

To estimate coffee ETc, the daily meteorological data were used during the conduction of the experiment, obtained through the meteorological station of the Goiano Federal Institute-Ceres Campus, which is located near the experimental area. Through the Class A tank, reference evapotranspiration (ETo) was estimated according to the Penman-Monteith model (Allen et al., 1998). The crop evapotranspiration (ETc) was determined as a function of the ETo values, taking into account the crop coefficient $(\mathrm{Kc})$ equal to 1 [new crop ( 1 to 3 years) and spacing $2-3.6 \times 0.5-1.0]$ (Oliveira et al., 2007).

The relative humidity was assigned by INMET, registered by the Automatic Meteorological Station, located in the Municipality of Itapaci-GO (Figure 2). The values of maximum, average and minimum temperatures during the period of the experiment are presented in Figure 3. The values of relative humidity and temperature were assigned by the National Institute of Meteorology (INMET), a meteorological station in the city of Itapaci, distant $51.1 \mathrm{~km}$ from the city of Ceres, and the weather conditions are similar to the location of the experiment. 


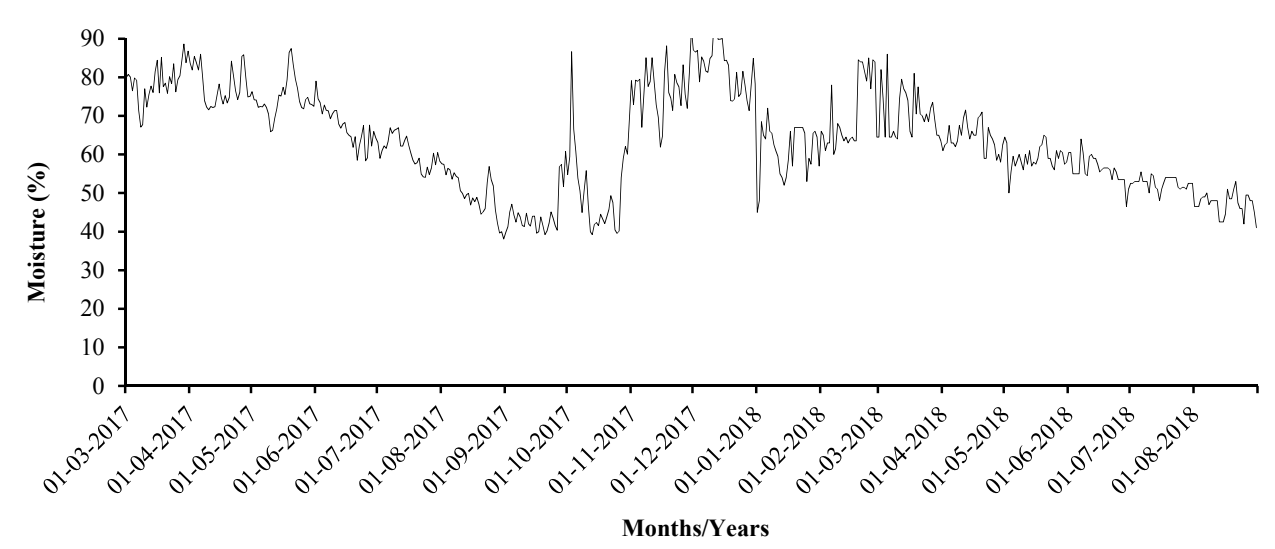

Figure 2. Relative air humidity

Note. Relative air humidity recorded from March 2017 to August 2018.

Source: INMET-Itapaci-GO.

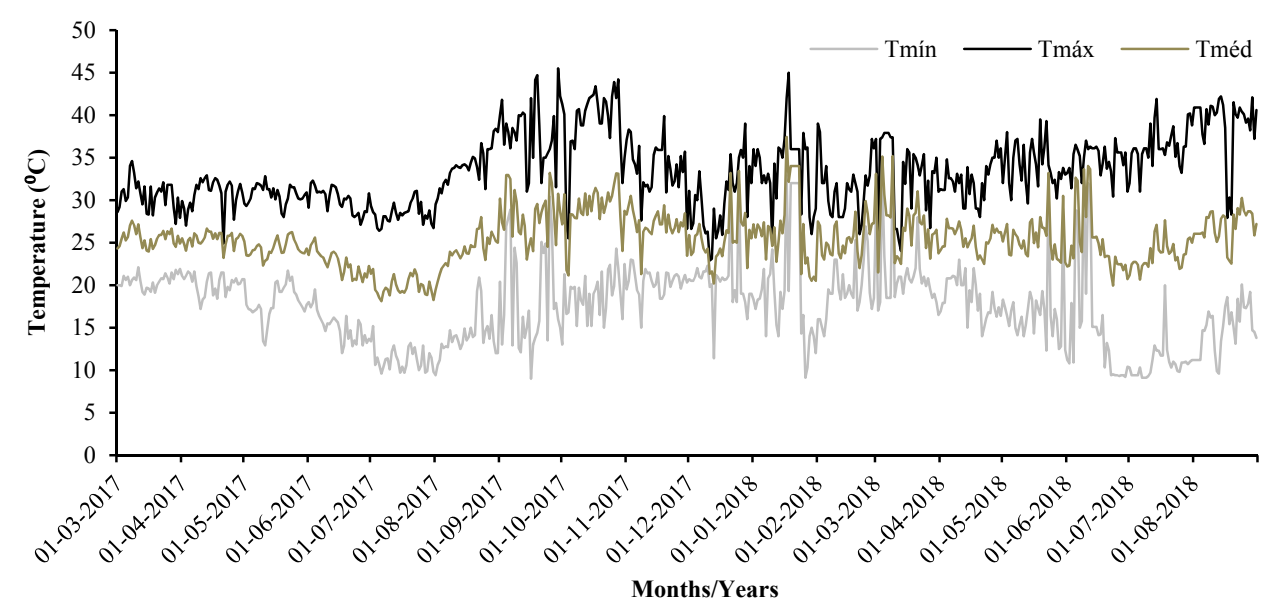

Figure 3. Maximum, average and minimum temperature

Note. Maximum, average and minimum temperature values from March 2017 to August 2018, in the municipality of Ceres-GO.

Source: INMET-Itapaci-GO.

The values of the daily readings of evapotranspiration of the Class A Tank of the Goiano IF-Ceres Campus from March 2017 to August 2018 are shown in Figure 4. 


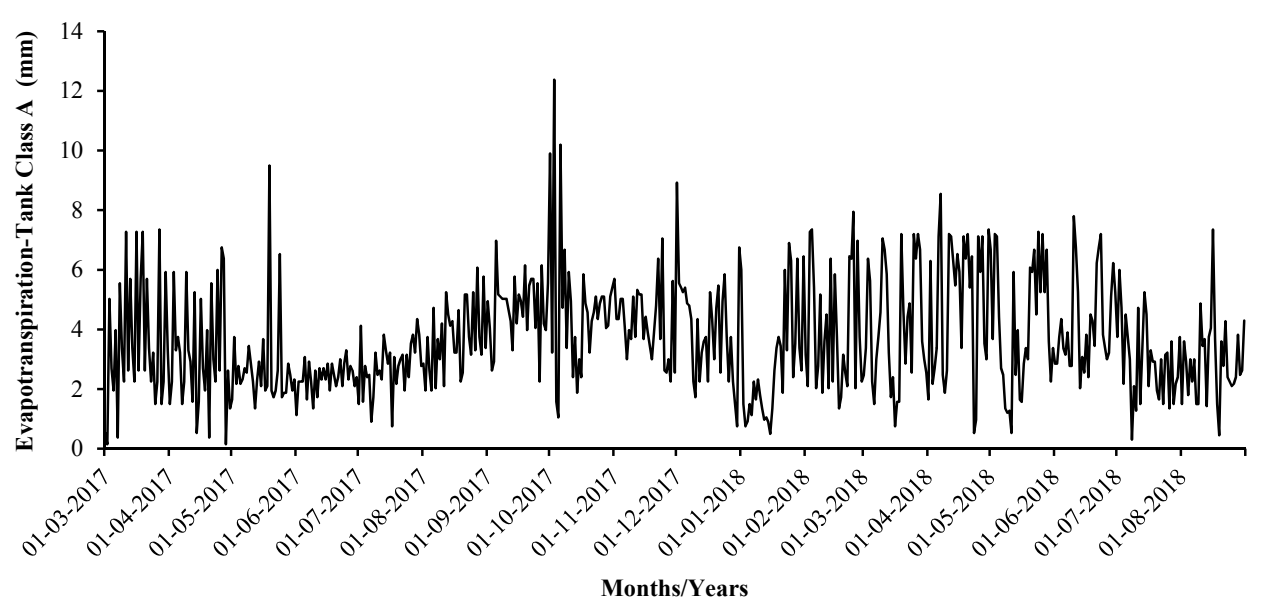

Figure 4. Evapotranspiration monitored by the class A tank

Note. Evapotranspiration monitored by the class A tank from March 2017 to October 2018. Source: Meteorological Station of the Goiano Federal Institute-Campus Ceres.

The pluviometric rainfall from March 2017 to August 2018, at the Goiano IF-Ceres Campus, based on data from the Itapaci-Goiás Automatic Weather Station, is described in Figure 5.

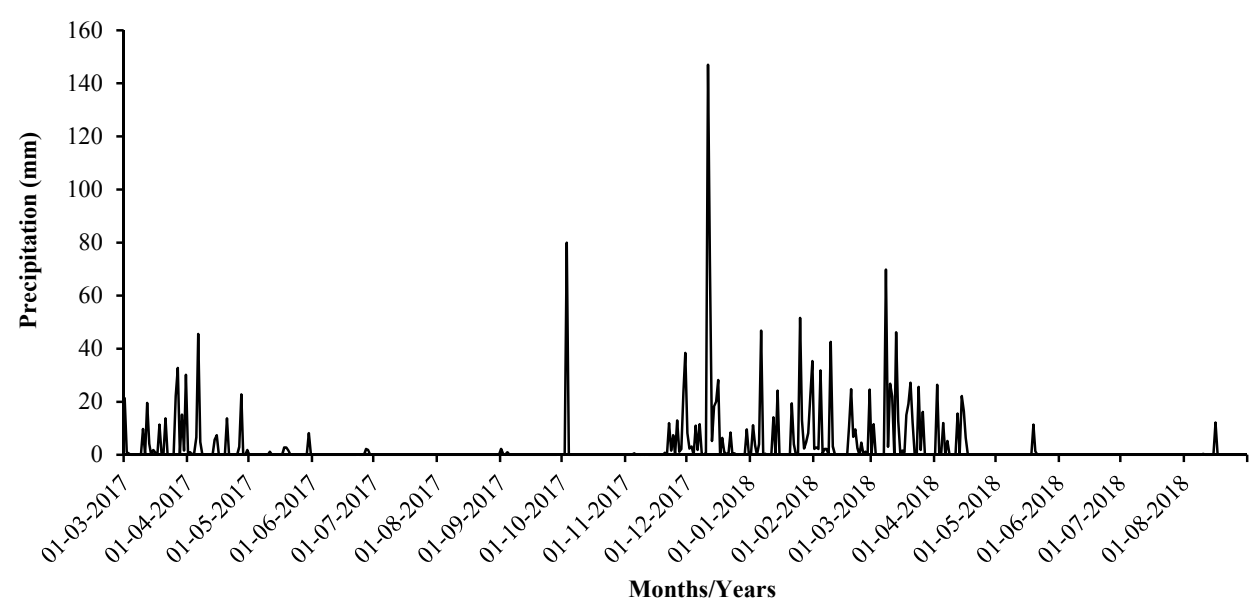

Figure 5. Pluviometric precipitation

Note. Pluviometric precipitation recorded from March 2017 to August 2018, at the Itapaci-GO Automatic Weather Station.

Source: INMET.

The variation values of the Photoperiod during the experiment period are shown in Figure 6. 


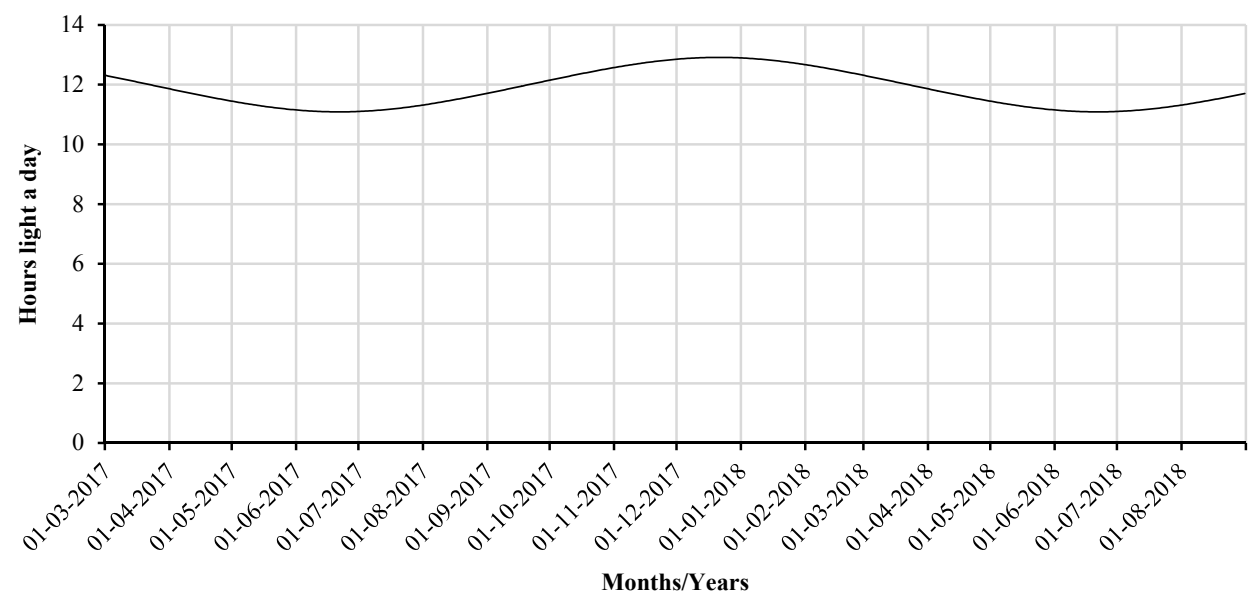

Figure 6. Photoperiod recorded during the conduction of the experiments

Note. Photoperiod recorded during the conduction of the experiments, from March 2017 to August 2018. Anápolis Station-GO, INMET (2018).

The amount of light hours per day varies, depending on the time of year. In Ceres-GO, in the period from March 2017 to August 2018, the minimum was $11 \mathrm{~h} ; 4 \mathrm{~min} ; 24 \mathrm{~s}$ in June and the maximum was $12 \mathrm{~h} ; 54 \mathrm{~min} ; 36 \mathrm{~s}$ in December (INMET, 2018).

The vegetative growth assessments were at 30 and 36 months after planting (MAP), in October 2017 and April 2018, respectively. In the four central plants, the diameter of the orthotropic branch, measured in millimeters, was evaluated with the aid of the digital caliper, at $5 \mathrm{~cm}$ from the ground; cup diameter, measured in centimeters; height of plant, in centimeters, measurement of soil level to the apical bud of the orthotropic branch; number of nodes of the orthotropic branch; number of nodes of plagiotropic branch 1, length of plagiotropic branch 1, number of nodes in plagiotropic branch 2, length of plagiotropic branch 2, length of plagiotropic branches 1 and 2 , number of nodes of plagiotropic branches 1 and 2. The length and number of nodes of the plagiotropic branches 1 and 2, are the ones that make up the second pair of branches, above the neck of the plant.

Fruit harvest was by manual melting in the cloth, in July 2018, when the majority of the fruits reached cherry or pass stage, and also the "sweeping" coffee was collected. The coffee harvested was dried in the sun, in terreiro and then heavy, in the form of coffee in coconut, which was benefited. The ratio between the amount of coffee in coconut and coffee benefited was obtained and, subsequently, the productivity of coffee benefited per portion of the useful area was calculated, thus determining the productivity per hectare.

The data obtained in the evaluations were submitted to analysis of variance using the SISVAR program and the comparison and grouping of means were performed by the Scott-Knott test, at 5\% probability of error. Simple linear correlation analysis was performed between all evaluated characteristics.

\section{Discussion}

The genotypes showed significant differences in relation to growth at $30 \mathrm{MAP}$ and $36 \mathrm{MAP}$ as well as in coffee productivity, as presented in Tables 1 and 2 . According to the presented productivity averages, the genotypes were divided into three groups: (13 genotypes), mean (13 genotypes) and lowest (nine genotypes) productivity (Figure 7). The correlation between productivity and the ten phenological characteristics evaluated at 36 months after planting was significant, except for number of nodes in the plagiotropic branch 2 (Table 3).

The genotypes Catiguá MG 1, Catuaí Vermelho IAC 15, Catucaí Amarelo 24/137, Acauã 2 and 8, Paraíso H 41910-6-2-10-1 presented smaller diameter of the orthotropic branch in the two evaluated periods, but are among the which belong to the group with the highest average productivity. The correlation was significant at $5 \%(0.17)$ between the number of bags of $60 \mathrm{~kg}$ of coffee benefited per hectare and the diameter of the orthotropic branch (Table 3). The correlation between the diameter of the orthotropic branch and plant height was significant at $1 \%$ $(0.69)$ as can be seen in Table 3. The Yellow Catucaí 2SL was the genotype with the best performance for these two characteristics, in the two evaluated epochs is in the group of the most productive genotypes. There is a growth synchrony between these two variables, to support the plant (Rodrigues et al., 2012). 
The correlation between canopy diameter and yield of coffee benefited per hectare was significant at $1 \%(0.36)$, as can be seen in Table 3. The IBC-Palma 2 was the one with the smallest crown diameter, in the two evaluated periods and also the lower productivity.

The Catucaí Amarelo 2SL showed higher plant height than the other genotypes in the two evaluated periods and also belongs to the most productive group. However, it is worth noting that there is a preference for lower plants, since it facilitates management and harvesting (Rodrigues et al., 2012). At 36 MAP, 12 genotypes were in the lowest group and three of them are also more productive: Catiguá MG 1, IPR 98 and Paraíso H 419-10-6-2-10-1.

Observing the number of nodes of the orthotropic branch, at the 30 MAPs, 11 genotypes are in the group that presented the greatest number of nodes (Table 1), but three of them had higher productivity: Araponga MG 1, Acauã and Acauã Novo. This was the only variable analyzed in which the Catucaí Amarelo 2SL did not present better performance in the two seasons and in the ten characteristics evaluated. With less orthotropic nodes, at the same evaluation time, there are four genotypes, but two of them are among the most productive: Sarchimor MG 8840 and Asa Branca.

The correlation between the number of nodes in the plagiotropic branch 2, at 36 months after planting and the productivity was not significant (0.12), as can be seen in Table 3. Study of four arabica coffee cultivars in the city of Ervália-MG, Martinez et al. (2007) found, at a spacing of $2.5 \times 0.75 \mathrm{~m}$, a non-significant correlation between MAP production and number of plagiotropic branches.

At 36 MAP, seven genotypes showed the highest number of orthotropic nodes (Table 2) and three of them were among the highest productivity (Figure 8), which are: Araponga MG 1, Catucaí Amarelo 2SL and Acauã. Among the four with the lowest numbers of orthotropic nodes, the White Wing is one of the most productive and the IBC-Palma 2 was the least productive of all the genotypes of the experiment. As shown, the number of nodes in the orthotropic branch did not influence productivity.

When evaluating the number of nodes of the plagiotropic branch 1, at the 30 MAPs, eight genotypes presented the highest values, three of them being among the ones that obtained the highest productivity: Catuaí Vermelho IAC 15, IPR 98, Catucaí Amarelo 2SL. Five genotypes had a smaller number of nodes of the plagiotropic branch 1, two of them being among the most productive: Araponga MG 1, Acauã 2 and 8 and one of them is the one that had the lowest productivity of all, the IBC-Palma 2, according to shows Table 2. At $36 \mathrm{MAP}$, according to Table 2, five genotypes had better performance and among these, two present higher productivity: Catuaí Vermelho IAC 15, Catucaí Amarelo 2SL. With less number of nodes of the plagiotropic branch 1, four genotypes, among them the IBC-Palma 2, with low productivity.

At 30 MAP, two genotypes showed lower length of the plagiotropic branch 1: Catiguá MG 3 and IBC-Palma 2 (Table 1). At 36 MAP, seven genotypes presented a lower length of the plagiotropic branch 1, two of them having high productivity: Catiguá MG 1, Acauã 2 and 8 and genotype IBC-Palma 2, with low productivity. With the longest length of the plagiotropic branch 1, in both evaluations was the Catucaí Amarelo 2SL, which also presented high productivity.

The variable length of the plagiotropic branch 2 was statistically divided into five groups at 30 MAP. With longer length is only the Catucaí Yellow 2SL. In the group with the lowest plagiotropic branch length 2, there are Oeiras MG 6851, Catiguá MG 1, Pau Brasil MG 1, Catiguá MG 3, Acauã 2 and 8 and IBC-Palma 2. The 36 MAPs are five groups with higher values of length are: Catucaí Amarelo 2SL, Catucaí Amarelo 20/15 cova 479, Sabiá Tardio or Sabiá 398 and Asa Branca. In the group of the lowest values are Oeiras MG 6851, Catiguá MG 3 and IBC-Palma 2. 
Table 1. Growth data of genotypes evaluated at 30 MAP

\begin{tabular}{|c|c|c|c|c|c|c|c|c|c|c|}
\hline Geno & $\mathrm{D}$ & Dcopa & Alt & NROrt & NRP1 & CRP1 & NRP2 & CRP2 & CTRP & NNTRP \\
\hline & \multicolumn{2}{|c|}{-------- mm ------- } & \multicolumn{3}{|l|}{$\mathrm{cm}$} & \multicolumn{2}{|l|}{$\mathrm{cm}$} & \multicolumn{2}{|c|}{--------- cm --------- } & \\
\hline Oeiras MG 6851 & $46.85 \mathrm{~d}$ & $132.38 \mathrm{e}$ & $182.69 \mathrm{f}$ & $38.94 \mathrm{c}$ & $17.63 \mathrm{c}$ & $62.75 \mathrm{~d}$ & $22.25 b$ & $73.25 \mathrm{e}$ & $136.00 \mathrm{e}$ & $39.88 \mathrm{c}$ \\
\hline Catiguá MG 1 & $46.69 d$ & $150.75 \mathrm{~d}$ & $183.50 \mathrm{f}$ & $39.19 \mathrm{c}$ & $18.50 \mathrm{c}$ & $65.13 \mathrm{c}$ & $24.06 \mathrm{~b}$ & $79.56 \mathrm{e}$ & $144.69 d$ & $42.56 \mathrm{c}$ \\
\hline Sacramento MG 1 & $53.43 b$ & $181.63 b$ & $210.50 c$ & $43.44 \mathrm{a}$ & $17.69 \mathrm{c}$ & $68.00 \mathrm{c}$ & $25.81 \mathrm{a}$ & $95.50 \mathrm{c}$ & $163.50 \mathrm{c}$ & $43.50 \mathrm{c}$ \\
\hline Catiguá MG 2 & $46.97 d$ & $148.06 \mathrm{~d}$ & $182.19 \mathrm{f}$ & $38.56 \mathrm{c}$ & $15.50 \mathrm{~d}$ & $60.00 \mathrm{~d}$ & $28.44 \mathrm{a}$ & $90.56 \mathrm{c}$ & $150.56 \mathrm{~d}$ & $43.94 \mathrm{c}$ \\
\hline Araponga MG 1 & $48.29 \mathrm{c}$ & $166.75 \mathrm{c}$ & $206.56 c$ & $44.56 \mathrm{a}$ & $16.56 \mathrm{~d}$ & $65.50 \mathrm{c}$ & $26.94 \mathrm{a}$ & $91.50 \mathrm{c}$ & $157.00 \mathrm{~d}$ & $43.50 \mathrm{c}$ \\
\hline Paraíso MG 419-1 & $46.99 \mathrm{~d}$ & $153.25 \mathrm{~d}$ & $182.81 \mathrm{f}$ & $41.25 \mathrm{~b}$ & $21.13 \mathrm{c}$ & $70.19 \mathrm{c}$ & $27.31 \mathrm{a}$ & $83.31 \mathrm{~d}$ & $153.50 \mathrm{~d}$ & $48.44 \mathrm{~b}$ \\
\hline Pau Brasil MG 1 & $48.52 \mathrm{c}$ & $132.25 \mathrm{e}$ & $181.25 \mathrm{f}$ & $40.63 b$ & $17.69 \mathrm{c}$ & $58.81 \mathrm{~d}$ & $23.56 \mathrm{~b}$ & $78.88 \mathrm{e}$ & $137.69 \mathrm{e}$ & $41.25 \mathrm{c}$ \\
\hline Catiguá MG 3 & $45.82 \mathrm{~d}$ & $118.38 \mathrm{f}$ & $178.69 f$ & $34.50 \mathrm{~d}$ & $12.38 \mathrm{~d}$ & $50.13 \mathrm{e}$ & $20.69 b$ & $76.38 \mathrm{e}$ & $126.50 \mathrm{e}$ & $33.06 \mathrm{~d}$ \\
\hline Topázio MG 1190 & $48.25 \mathrm{c}$ & $165.06 \mathrm{c}$ & $192.63 d$ & $42.75 \mathrm{a}$ & $21.19 \mathrm{c}$ & $71.50 \mathrm{c}$ & $29.88 \mathrm{a}$ & $92.50 \mathrm{c}$ & $164.00 \mathrm{c}$ & $51.06 \mathrm{~b}$ \\
\hline $23 \mathrm{II}$ & $52.45 \mathrm{~b}$ & $169.88 \mathrm{c}$ & $198.50 \mathrm{~d}$ & $37.44 \mathrm{c}$ & $19.44 \mathrm{c}$ & $80.69 b$ & $24.00 \mathrm{~b}$ & $94.69 \mathrm{c}$ & $175.38 \mathrm{~b}$ & $43.44 \mathrm{c}$ \\
\hline IPR 104 & $48.77 \mathrm{c}$ & $159.88 \mathrm{c}$ & $188.06 \mathrm{e}$ & $41.50 \mathrm{~b}$ & $23.88 \mathrm{~b}$ & & $27.13 \mathrm{a}$ & $87.19 \mathrm{~d}$ & $162.44 \mathrm{c}$ & $51.00 \mathrm{~b}$ \\
\hline Sarchimor MG 8840 & $51.01 \mathrm{~b}$ & $165.25 \mathrm{c}$ & $194.69 d$ & $35.44 d$ & $20.19 \mathrm{c}$ & $74.00 \mathrm{c}$ & $25.06 \mathrm{~b}$ & $89.00 \mathrm{c}$ & $163.00 \mathrm{c}$ & $45.25 \mathrm{c}$ \\
\hline Catucaí Vermelho 20/1 & $46.12 d$ & $156.75 d$ & $189.19 \mathrm{e}$ & $42.63 \mathrm{a}$ & $21.81 \mathrm{~b}$ & $72.56 \mathrm{c}$ & $28.38 \mathrm{a}$ & $90.13 \mathrm{c}$ & $162.69 \mathrm{c}$ & $50.19 \mathrm{~b}$ \\
\hline Tupi & $45.58 \mathrm{~d}$ & $146.44 d$ & & & & & & & & $42.19 \mathrm{c}$ \\
\hline Obatã Vermelho IAC 1669-20 & $49.50 \mathrm{c}$ & $179.75 b$ & $190.75 \mathrm{e}$ & $38.38 \mathrm{c}$ & $24.06 \mathrm{~b}$ & $82.44 \mathrm{~b}$ & $28.38 \mathrm{a}$ & $94.56 \mathrm{c}$ & $177.00 \mathrm{~b}$ & $52.44 \mathrm{~b}$ \\
\hline Obatã Amarelo IAC 4932 & $49.80 \mathrm{c}$ & $152.88 \mathrm{~d}$ & $182.25 \mathrm{f}$ & $35.38 \mathrm{~d}$ & $17.63 \mathrm{c}$ & $63.69 \mathrm{~d}$ & $22.88 \mathrm{~b}$ & $86.50 \mathrm{~d}$ & $150.19 \mathrm{~d}$ & $40.50 \mathrm{c}$ \\
\hline Catuaí Verme & $46.00 \mathrm{~d}$ & & & & & & & & & $52.75 \mathrm{~b}$ \\
\hline Catuaí Amarelo IAC 062 & $47.80 \mathrm{~d}$ & $175.31 \mathrm{~b}$ & $199.38 \mathrm{~d}$ & $42.94 a$ & $26.69 \mathrm{a}$ & $83.50 \mathrm{~b}$ & $30.13 \mathrm{a}$ & $95.88 \mathrm{c}$ & $179.38 b$ & $56.81 \mathrm{a}$ \\
\hline IPR 98 & $48.98 \mathrm{c}$ & $172.06 \mathrm{c}$ & $186.44 \mathrm{e}$ & $41.06 \mathrm{~b}$ & $27.94 \mathrm{a}$ & $83.81 \mathrm{~b}$ & $27.63 \mathrm{a}$ & $87.88 \mathrm{~d}$ & $171.69 \mathrm{c}$ & $55.56 \mathrm{a}$ \\
\hline IPR 99 & $50.61 \mathrm{c}$ & $161.81 \mathrm{c}$ & & $39.25 \mathrm{c}$ & $20.81 \mathrm{c}$ & & & & & $47.94 b$ \\
\hline IPR 100 & $48.82 \mathrm{c}$ & $179.56 b$ & $192.44 d$ & $42.56 \mathrm{a}$ & $30.63 \mathrm{a}$ & $91.00 \mathrm{~b}$ & $28.75 \mathrm{a}$ & $92.00 \mathrm{c}$ & $183.00 \mathrm{~b}$ & $59.38 \mathrm{a}$ \\
\hline IPR 103 & $49.36 \mathrm{c}$ & $179.88 b$ & $201.38 \mathrm{~d}$ & $41.50 \mathrm{~b}$ & $22.44 b$ & $82.19 b$ & $29.43 \mathrm{a}$ & $99.44 \mathrm{c}$ & $181.63 b$ & $51.88 \mathrm{~b}$ \\
\hline Catucaí Amarelo 2SL & $60.47 \mathrm{a}$ & $220.56 a$ & $268.69 \mathrm{a}$ & $42.25 b$ & $30.88 \mathrm{a}$ & $111.13 \mathrm{a}$ & $27.50 \mathrm{a}$ & $115.63 \mathrm{a}$ & $226.75 a$ & $58.38 \mathrm{a}$ \\
\hline Catucaí Amarelo 24/137 & $46.96 \mathrm{~d}$ & $160.06 \mathrm{c}$ & $196.13 d$ & $40.63 b$ & $21.69 \mathrm{~b}$ & $71.69 \mathrm{c}$ & $26.81 \mathrm{a}$ & $89.81 \mathrm{c}$ & $161.50 \mathrm{c}$ & $48.50 \mathrm{~b}$ \\
\hline Catucaí Amarelo 20/15 cova 479 & $51.66 \mathrm{~b}$ & $188.00 \mathrm{~b}$ & $221.13 b$ & $45.94 \mathrm{a}$ & $29.25 \mathrm{a}$ & $91.31 \mathrm{~b}$ & $30.88 \mathrm{a}$ & $97.75 \mathrm{c}$ & $189.06 b$ & $60.13 \mathrm{a}$ \\
\hline Catucaí Vermelho 785/15 & $47.65 \mathrm{~d}$ & $138.94 \mathrm{e}$ & $188.44 \mathrm{e}$ & $43.88 \mathrm{a}$ & $23.94 b$ & $70.31 \mathrm{c}$ & $30.81 \mathrm{a}$ & & $156.38 \mathrm{~d}$ & $54.75 \mathrm{a}$ \\
\hline Acauã $2 \& 8$ & $47.28 \mathrm{~d}$ & $145.88 \mathrm{~d}$ & $186.13 \mathrm{e}$ & $40.94 b$ & $16.44 d$ & $59.19 \mathrm{~d}$ & $21.19 \mathrm{~b}$ & $72.44 \mathrm{e}$ & $131.63 \mathrm{e}$ & $37.63 \mathrm{~d}$ \\
\hline Sabiá Tardio ou Sabiá 398 & $47.20 \mathrm{~d}$ & $183.94 b$ & $192.00 \mathrm{~d}$ & $43.19 \mathrm{a}$ & $27.50 \mathrm{a}$ & $86.31 \mathrm{~b}$ & $34.19 \mathrm{a}$ & $101.38 \mathrm{~b}$ & $187.69 \mathrm{~b}$ & $61.69 \mathrm{a}$ \\
\hline Asa Branca & $48.48 \mathrm{c}$ & $189.06 b$ & $193.94 d$ & $36.25 \mathrm{~d}$ & $23.88 \mathrm{~b}$ & $88.81 \mathrm{~b}$ & $26.88 \mathrm{a}$ & $104.13 b$ & $192.94 b$ & $50.75 b$ \\
\hline IBC-Palma 2 & $46.94 d$ & $85.06 \mathrm{~g}$ & $189.44 \mathrm{e}$ & $38.44 \mathrm{c}$ & $12.75 \mathrm{~d}$ & $46.38 \mathrm{e}$ & $19.06 \mathrm{~b}$ & $71.63 \mathrm{e}$ & $118.00 \mathrm{e}$ & $31.81 \mathrm{~d}$ \\
\hline Acauã & $49.62 \mathrm{c}$ & $174.13 b$ & $194.88 \mathrm{~d}$ & $42.44 a$ & $25.31 b$ & $81.88 \mathrm{~b}$ & $26.31 \mathrm{a}$ & $89.19 \mathrm{c}$ & $171.06 \mathrm{c}$ & $51.63 \mathrm{~b}$ \\
\hline Acauã Novo & $47.90 \mathrm{~d}$ & $176.56 \mathrm{~b}$ & $193.50 \mathrm{~d}$ & $43.69 \mathrm{a}$ & $22.81 \mathrm{~b}$ & $74.94 \mathrm{c}$ & $27.38 \mathrm{a}$ & $93.75 \mathrm{c}$ & $168.69 \mathrm{c}$ & $50.19 \mathrm{~b}$ \\
\hline H-419-3-3-7-16-4-1 & $49.29 \mathrm{c}$ & $170.44 \mathrm{c}$ & $188.13 \mathrm{e}$ & $40.19 b$ & $27.63 \mathrm{a}$ & $87.31 \mathrm{~b}$ & $28.06 \mathrm{a}$ & $93.13 \mathrm{c}$ & $180.44 b$ & $55.69 \mathrm{a}$ \\
\hline Paraíso H 419-10-6-2-12-1 & $44.86 \mathrm{~d}$ & $150.75 \mathrm{~d}$ & $174.06 \mathrm{f}$ & $39.81 \mathrm{c}$ & $22.31 b$ & $72.06 \mathrm{c}$ & $26.94 \mathrm{a}$ & $81.38 \mathrm{~d}$ & $153.44 d$ & $49.25 b$ \\
\hline Paraíso H 419-10-6-2-10-1 & $47.59 \mathrm{~d}$ & $155.19 \mathrm{~d}$ & $175.19 \mathrm{f}$ & $38.75 \mathrm{c}$ & $22.56 b$ & $74.44 \mathrm{c}$ & $26.56 \mathrm{a}$ & $87.31 \mathrm{~d}$ & $161.75 \mathrm{c}$ & $49.13 b$ \\
\hline CV $(\%)$ & 9.61 & 11.87 & 6.96 & 9.14 & 31.13 & 22.75 & 23.88 & 16.68 & 15.35 & 20.60 \\
\hline
\end{tabular}

Note. Diameter of the orthotropic branch (D), Cup diameter (Dcopa), Plant height (Alt), Number of nodes of the orthotropic branch (NROrt), Number of nodes of plagiotropic branch 1 (NRP1), Length of plagiotropic branch 1, number of nodes in the plagiotropic branch 2 (NRP2), length of the plagiotropic branch 2 (CRP2), length of the plagiotropic branches 1 and 2 (CTRP), number of nodes of the plagiotropic branches 1 and 2 (NNTRP) genotypes of Coffea arabica at 30 months of age. Means followed by the same lowercase vertical letter do not differ by Scott-Knott test at the 5\% error probability level. 
Table 2. Growth data of genotypes evaluated at 36 MAP

\begin{tabular}{|c|c|c|c|c|c|c|c|c|c|c|}
\hline Genotypes & $\mathrm{D}$ & Dcopa & Alt $(\mathrm{cm})$ & NROrt & NRP1 & CRP1 & NRP2 & CRP2 & CTRP & NNTRP \\
\hline & \multicolumn{2}{|c|}{-------- mm ------- } & \multicolumn{3}{|l|}{$\mathrm{cm}$} & \multicolumn{2}{|l|}{$\mathrm{cm}$} & \multicolumn{2}{|c|}{--------- cm --------- } & \\
\hline Oeiras MG 6851 & $55.38 \mathrm{c}$ & $143.63 \mathrm{f}$ & $202.13 \mathrm{e}$ & $46.13 \mathrm{c}$ & $16.56 \mathrm{~d}$ & $65.44 \mathrm{e}$ & $25.13 \mathrm{c}$ & $77.25 \mathrm{~d}$ & $142.69 \mathrm{e}$ & $41.69 \mathrm{c}$ \\
\hline Catiguá MG 1 & $57.71 \mathrm{c}$ & $165.63 \mathrm{e}$ & $208.06 \mathrm{e}$ & $46.38 \mathrm{c}$ & $19.38 \mathrm{c}$ & $67.31 \mathrm{e}$ & $25.88 \mathrm{c}$ & $91.06 \mathrm{c}$ & $158.38 \mathrm{~d}$ & $45.25 \mathrm{c}$ \\
\hline Sacramento MG 1 & $63.06 \mathrm{~b}$ & $181.25 \mathrm{c}$ & $225.69 \mathrm{c}$ & $50.75 b$ & $22.81 \mathrm{~b}$ & $84.81 \mathrm{c}$ & $28.81 \mathrm{~b}$ & $106.81 \mathrm{~b}$ & $191.63 \mathrm{c}$ & $51.63 \mathrm{~b}$ \\
\hline Catiguá MG 2 & $57.07 \mathrm{c}$ & $150.44 f$ & $199.75 \mathrm{e}$ & $46.13 \mathrm{c}$ & $15.81 \mathrm{~d}$ & $59.81 \mathrm{e}$ & $25.19 \mathrm{c}$ & $87.88 \mathrm{c}$ & $147.69 d$ & $41.00 \mathrm{c}$ \\
\hline Araponga MG 1 & $56.33 \mathrm{c}$ & $169.00 \mathrm{~d}$ & $221.06 c$ & $51.25 \mathrm{a}$ & $19.31 \mathrm{c}$ & $78.00 \mathrm{c}$ & $28.63 b$ & $97.69 \mathrm{~b}$ & $175.69 \mathrm{c}$ & $47.94 \mathrm{c}$ \\
\hline Paraíso MG 419-1 & $55.21 \mathrm{c}$ & $156.44 \mathrm{e}$ & $203.00 \mathrm{e}$ & $48.25 b$ & $24.56 \mathrm{~b}$ & $75.69 \mathrm{~d}$ & $28.06 \mathrm{~b}$ & $90.94 \mathrm{c}$ & $166.63 d$ & $52.63 \mathrm{~b}$ \\
\hline Pau Brasil MG 1 & $56.68 \mathrm{c}$ & $157.38 \mathrm{e}$ & $200.69 \mathrm{e}$ & $46.06 \mathrm{c}$ & $19.25 \mathrm{c}$ & $65.75 \mathrm{e}$ & $27.13 \mathrm{c}$ & $87.75 \mathrm{c}$ & $153.50 \mathrm{~d}$ & $46.38 \mathrm{c}$ \\
\hline Catiguá MG 3 & $55.65 \mathrm{c}$ & $126.75 \mathrm{~g}$ & $195.06 \mathrm{e}$ & $39.88 \mathrm{~d}$ & $13.63 \mathrm{~d}$ & $54.19 \mathrm{e}$ & $21.06 \mathrm{~d}$ & $74.13 \mathrm{~d}$ & $128.31 \mathrm{e}$ & $34.69 \mathrm{~d}$ \\
\hline Topázio MG 1190 & $58.32 \mathrm{~b}$ & $176.63 \mathrm{~d}$ & $216.00 \mathrm{~d}$ & $52.25 \mathrm{a}$ & $25.69 \mathrm{~b}$ & $79.88 \mathrm{c}$ & $33.88 \mathrm{a}$ & $103.44 b$ & $183.31 \mathrm{c}$ & $59.56 \mathrm{a}$ \\
\hline $23 \mathrm{II}$ & $60.20 \mathrm{~b}$ & $177.75 \mathrm{~d}$ & $217.00 \mathrm{~d}$ & $44.50 \mathrm{c}$ & $21.50 \mathrm{c}$ & $86.50 \mathrm{c}$ & $28.75 b$ & $100.94 b$ & $187.44 \mathrm{c}$ & $50.25 \mathrm{c}$ \\
\hline IPR 104 & $57.44 \mathrm{c}$ & $175.81 \mathrm{~d}$ & $213.94 d$ & $50.06 \mathrm{~b}$ & $24.25 b$ & $79.75 \mathrm{c}$ & $29.19 b$ & $94.88 \mathrm{~b}$ & $174.63 \mathrm{c}$ & $53.44 \mathrm{~b}$ \\
\hline Sarchimor MG 8840 & $59.41 \mathrm{~b}$ & $172.00 \mathrm{~d}$ & $214.88 \mathrm{~d}$ & $45.25 \mathrm{c}$ & $20.00 \mathrm{c}$ & $76.63 \mathrm{~d}$ & $26.81 \mathrm{c}$ & $98.69 \mathrm{~b}$ & $175.31 \mathrm{c}$ & $46.81 \mathrm{c}$ \\
\hline Catucaí Vermelho20/15cc & $57.66 \mathrm{c}$ & $170.44 d$ & $219.69 \mathrm{c}$ & $52.81 \mathrm{a}$ & $24.94 b$ & $82.63 \mathrm{c}$ & $29.75 b$ & $98.75 b$ & $181.38 \mathrm{c}$ & $54.69 \mathrm{~b}$ \\
\hline Tupi I & $52.59 \mathrm{c}$ & $157.13 \mathrm{e}$ & & & & & & & & $44.94 \mathrm{c}$ \\
\hline Obatã Vermelho IAC 1669-20 & $60.73 b$ & $187.69 \mathrm{c}$ & $212.06 \mathrm{~d}$ & $45.44 \mathrm{c}$ & $24.69 b$ & $84.19 \mathrm{c}$ & $28.75 b$ & $99.50 \mathrm{~b}$ & $183.69 \mathrm{c}$ & $53.44 \mathrm{~b}$ \\
\hline Obatã Amarelo IAC 4932 & $60.95 \mathrm{~b}$ & $170.81 \mathrm{~d}$ & $203.13 \mathrm{e}$ & $43.81 \mathrm{~d}$ & $20.81 \mathrm{c}$ & $74.81 \mathrm{~d}$ & $24.81 \mathrm{c}$ & $96.44 \mathrm{~b}$ & $171.25 \mathrm{c}$ & $45.63 \mathrm{c}$ \\
\hline Catuaí Vermelho IAC 15 & & $179.94 \mathrm{c}$ & & & & & & & & $57.88 \mathrm{~b}$ \\
\hline Catuaí Amarelo IAC 062 & $58.60 \mathrm{~b}$ & $181.06 \mathrm{c}$ & $223.13 c$ & $50.81 \mathrm{~b}$ & $26.00 \mathrm{~b}$ & $87.06 \mathrm{c}$ & $30.81 \mathrm{~b}$ & $101.81 \mathrm{~b}$ & $188.88 \mathrm{c}$ & $56.81 \mathrm{~b}$ \\
\hline IPR 98 & $56.54 \mathrm{c}$ & $178.00 \mathrm{~d}$ & $208.75 \mathrm{e}$ & $50.69 \mathrm{~b}$ & $25.38 \mathrm{~b}$ & $80.50 \mathrm{c}$ & $29.44 b$ & $96.75 b$ & $177.25 \mathrm{c}$ & $54.81 \mathrm{~b}$ \\
\hline IPR 99 & $59.62 b$ & $175.94 d$ & $211.06 \mathrm{~d}$ & $48.13 b$ & $22.63 b$ & & & & $178.88 \mathrm{c}$ & $51.50 \mathrm{~b}$ \\
\hline IPR 100 & $59.95 \mathrm{~b}$ & $200.25 b$ & $217.06 \mathrm{~d}$ & $50.31 \mathrm{~b}$ & $32.06 \mathrm{a}$ & $98.56 \mathrm{~b}$ & $33.44 \mathrm{a}$ & $105.31 \mathrm{~b}$ & $203.88 b$ & $65.50 \mathrm{a}$ \\
\hline IPR 103 & $58.60 \mathrm{~b}$ & $193.19 b$ & $226.81 \mathrm{c}$ & $49.13 b$ & $24.69 b$ & $87.69 \mathrm{c}$ & $31.56 \mathrm{~b}$ & $105.81 \mathrm{~b}$ & $193.50 \mathrm{c}$ & $56.25 \mathrm{~b}$ \\
\hline Catucaí Amarelo 2SL & $75.77 \mathrm{a}$ & $225.13 \mathrm{a}$ & $292.50 \mathrm{a}$ & $51.44 \mathrm{a}$ & $30.63 a$ & $111.56 \mathrm{a}$ & $30.38 b$ & $123.13 \mathrm{a}$ & $235.69 \mathrm{a}$ & $61.00 \mathrm{a}$ \\
\hline Catucaí Amarelo 24/137 & $57.14 \mathrm{c}$ & $166.13 \mathrm{e}$ & $226.81 \mathrm{c}$ & $49.69 b$ & $23.06 \mathrm{~b}$ & $79.44 \mathrm{c}$ & $28.25 b$ & $92.44 \mathrm{c}$ & $171.88 \mathrm{c}$ & $51.31 \mathrm{~b}$ \\
\hline Catucaí Amarelo 20/15 cova 479 & $60.66 \mathrm{~b}$ & $198.88 b$ & $247.94 b$ & $54.69 \mathrm{a}$ & $29.81 \mathrm{a}$ & $96.56 \mathrm{~b}$ & $34.56 \mathrm{a}$ & $109.00 \mathrm{a}$ & $205.56 b$ & $64.38 \mathrm{a}$ \\
\hline Catucaí Vermelho 785/15 & $58.23 \mathrm{~b}$ & $147.13 \mathrm{f}$ & $212.69 \mathrm{~d}$ & $52.31 \mathrm{a}$ & $23.38 \mathrm{~b}$ & $71.75 \mathrm{~d}$ & $31.56 \mathrm{~b}$ & $89.06 \mathrm{c}$ & $160.81 d$ & $54.94 \mathrm{~b}$ \\
\hline Acauã $2 \& 8$ & $58.46 \mathrm{~b}$ & $159.25 \mathrm{e}$ & $214.13 d$ & $48.19 b$ & $18.81 \mathrm{c}$ & $65.69 \mathrm{e}$ & $26.69 \mathrm{c}$ & $85.38 \mathrm{c}$ & $151.06 \mathrm{~d}$ & $45.50 \mathrm{c}$ \\
\hline Sabiá Tardio ou Sabiá 398 & $55.36 \mathrm{c}$ & $192.75 b$ & $214.25 \mathrm{~d}$ & $50.19 \mathrm{~b}$ & $28.88 \mathrm{a}$ & $93.88 \mathrm{~b}$ & $38.06 \mathrm{a}$ & $116.19 \mathrm{a}$ & $210.06 b$ & $66.94 \mathrm{a}$ \\
\hline Asa Branca & $56.41 \mathrm{c}$ & $190.69 b$ & $214.44 d$ & $42.50 \mathrm{~d}$ & $25.94 b$ & $100.31 \mathrm{~b}$ & $29.94 b$ & $113.44 \mathrm{a}$ & $213.75 b$ & $55.88 \mathrm{~b}$ \\
\hline IBC-Palma 2 & $54.91 \mathrm{c}$ & $115.38 \mathrm{~g}$ & $202.13 \mathrm{e}$ & $42.13 \mathrm{~d}$ & $15.19 \mathrm{~d}$ & $56.75 \mathrm{e}$ & $17.31 \mathrm{~d}$ & $66.12 \mathrm{~d}$ & $122.88 \mathrm{e}$ & $32.50 \mathrm{~d}$ \\
\hline Acauã & $56.32 \mathrm{c}$ & $186.50 \mathrm{c}$ & $220.13 c$ & $51.38 \mathrm{a}$ & $25.38 \mathrm{~b}$ & $82.94 \mathrm{c}$ & $30.69 b$ & $99.19 b$ & $182.13 \mathrm{c}$ & $56.06 \mathrm{~b}$ \\
\hline Acauã Novo & $58.94 \mathrm{~b}$ & $186.75 \mathrm{c}$ & $216.56 \mathrm{~d}$ & $50.13 b$ & $21.50 \mathrm{c}$ & $71.81 \mathrm{~d}$ & $28.25 b$ & $95.63 b$ & $167.44 d$ & $49.75 \mathrm{c}$ \\
\hline H-419-3-3-7-16-4-1 & $55.42 \mathrm{c}$ & $179.13 \mathrm{c}$ & $210.44 d$ & $49.19 b$ & $22.25 \mathrm{c}$ & $83.38 \mathrm{c}$ & $30.69 \mathrm{~b}$ & $100.56 b$ & $183.94 \mathrm{c}$ & $52.94 \mathrm{~b}$ \\
\hline Paraíso H 419-10-6-2-12-1 & $57.42 \mathrm{c}$ & $155.56 \mathrm{e}$ & $198.06 \mathrm{e}$ & $48.94 b$ & $21.38 \mathrm{c}$ & $75.75 \mathrm{~d}$ & $24.69 \mathrm{c}$ & $83.63 \mathrm{c}$ & $159.38 \mathrm{~d}$ & $46.06 \mathrm{c}$ \\
\hline Paraíso H 419-10-6-2-10-1 & $55.18 \mathrm{c}$ & $158.94 \mathrm{e}$ & $194.88 \mathrm{e}$ & $46.31 \mathrm{c}$ & $22.81 \mathrm{~b}$ & $79.25 \mathrm{c}$ & $26.94 \mathrm{c}$ & $93.94 b$ & $173.19 \mathrm{c}$ & $49.75 \mathrm{c}$ \\
\hline $\mathrm{CV}(\%)$ & 9.67 & 9.68 & 6.29 & 9.43 & 25.76 & 20.01 & 22.16 & 15.63 & 14.05 & 18.66 \\
\hline
\end{tabular}

Note. Diameter of the orthotropic branch (D), Cup diameter (Dcopa), Plant height (Alt), Number of nodes of the orthotropic branch (NROrt), Number of nodes of plagiotropic branch 1 (NRP1), Length of plagiotropic branch 1, number of nodes in plagiotropic branch 2 (NRP2), length of plagiotropic branch 2 (CRP2), length of plagiotropic branches 1 and 2 (CTRP), number of nodes in plagiotropic branches 1 and 2 (NNTRP) in Coffea arabica genotypes at 36 months of age. Means followed by the same lowercase vertical letter do not differ by Scott-Knott test at the $5 \%$ error probability level. 
Table 3. The correlation between productivity and the ten phenological characteristics evaluated at 36 months after planting

\begin{tabular}{|c|c|c|c|c|c|c|c|c|c|c|c|}
\hline & $\mathrm{sc} \mathrm{ha}^{-1}$ & $\mathrm{D}$ & Dcopa & Alt & NROrt & NRP1 & CRP1 & NRP2 & CRP2 & CTRP & NNTRP \\
\hline $\mathrm{sc} \mathrm{ha}^{-1}$ & 1.00 & & & & & & & & & & \\
\hline D & $0.17^{*}$ & 1.00 & & & & & & & & & \\
\hline Dcopa & $0.36^{* *}$ & $0.52^{* *}$ & 1.00 & & & & & & & & \\
\hline Alt & $0.22^{* *}$ & $0.69^{* *}$ & $0.69^{* *}$ & 1.00 & & & & & & & \\
\hline NROrt & $0.17^{*}$ & $0.24^{* *}$ & $0.46^{* *}$ & $0.54^{* *}$ & 1.00 & & & & & & \\
\hline NRP1 & $0.26^{* *}$ & $0.31^{* *}$ & $0.73^{* *}$ & $0.49^{* *}$ & $0.46^{* *}$ & 1.00 & & & & & \\
\hline CRP1 & $0.24^{* *}$ & $0.41^{* *}$ & $0.78^{* *}$ & $0.57^{* *}$ & $0.38^{* *}$ & $0.86^{* *}$ & 1.00 & & & & \\
\hline NRP2 & $0.12^{\mathrm{ns}}$ & $0.19^{*}$ & $0.64^{* *}$ & $0.40^{* *}$ & $0.57^{* *}$ & $0.66^{* *}$ & $0.59^{* *}$ & 1.00 & & & \\
\hline CRP2 & $0.23^{* *}$ & $0.46^{* *}$ & $0.83^{* *}$ & $0.61^{* *}$ & $0.45^{* *}$ & $0.67^{* *}$ & $0.75^{* *}$ & $0.77^{* *}$ & 1.00 & & \\
\hline CTRP & $0.25^{* *}$ & $0.46^{* *}$ & $0.86^{* *}$ & $0.63^{* *}$ & $0.44^{* *}$ & $0.82^{* *}$ & $0.94^{* *}$ & $0.72^{* *}$ & $0.93^{* *}$ & 1.00 & \\
\hline NNTRP & $0.21^{* *}$ & $0.28^{* *}$ & $0.75^{* *}$ & $0.49^{* *}$ & $0.56^{* *}$ & $0.92^{* *}$ & $0.80^{* *}$ & $0.90^{* *}$ & $0.79^{* *}$ & $0.85^{* *}$ & 1.00 \\
\hline
\end{tabular}

Note. Simple correlation (r) between the variables analyzed, productivity in coffee bags benefited, per hectare (sc $\mathrm{ha}^{-1}$ ), diameter of the orthotropic branch (D), cup diameter (Dcopa), plant height ), number of nodes in the plagiotropic branch 2 (NRP2), number of nodes in the plagiotropic branch 2 (CPR2), number of nodes in the plagiotropic branch 2 (NRP2), number of nodes in the plagiotropic branch 1 (NRP1) ), length of plagiotropic branches 1 and 2 (CTRP), number of nodes of plagiotropic branches 1 and 2 (NNTRP), in the year 2018, of 35 genotypes of Coffea arabica, at 36 MAPs. Ceres-GO, 2018. **, * are significant at 1 and $5 \%$ of error probability, respectively. $\mathrm{ns}=$ not significant.

The correlation of the variable length of the plagiotropic branch 2, at $36 \mathrm{MAP}$, was significant at $1 \%$, with the length of the plagiotropic branch 1 (0.75), the number of nodes in the plagiotropic branch $2(0.77)$, the number of in the plagiotropic branches $(0.79)$ and in the crown diameter $(0.83)$, as shown in Table 3 .

With the longest length of the plagiotropic branches, at $30 \mathrm{MAP}$ and at $36 \mathrm{MAP}$, there is only Catucaí Amarelo 2SL. With the lowest values in the length of the plagiotropic branches, the 30 MAPs are: Oeiras MG 6851, Pau Brasil MG 1, Catiguá MG 3, Acauã 2 and 8 and IBC-Palma 2. The 36 MAPs in the group of the lowest values are: Oeiras MG 6851, Catiguá MG 3 and IBC-Palma 2.

As shown in Table 3, the correlation was significant at $1 \%$, between the variable length of the plagiotropic branches with: crown diameter (0.86), number of nodes in the plagiotropic branch $1(0.82)$, number of nodes in the plagiotropic branch 1 (0.94), plagiotropic branch length $2(0.93)$ and productivity $(0.25)$.

The number of nodes is important because it indicates how many productive buds exist in the plagiotropic branches, thus being very relevant for productivity (Assis et al., 2018). At 30 MAP, eight genotypes showed higher numbers of total nodes in the plagiotropic branches: Catuaí Amarelo IAC 062, IPR 98, IPR 100, Catucaí Amarelo 2SL, Catucaí Amarelo 20/15 cova 479, Catucaí Vermelho 785/15, Sabiá Tardio or Sabiá 398 and H-419-3-3-7-16-4-1. Among these, the IPR 98 and Catucaí Amarelo 2SL are also in the group of genotypes with higher productivity.

At 36 MAP, in the group with the largest numbers of total nodes in the plagiotropic branches are: Topázio MG 1190, IPR 100, Catucaí Amarelo 2SL, Catucaí Amarelo 20/15 cova 479, Sabiá Tardio or Sabiá 398. Only Catucaí Amarelo 2SL is in the group of the most productive. The genotypes with the lowest numbers of total nodes in the plagiotropic branches at the 30 MAPs were: Catiguá MG 3, Acauã 2 and 8 (belonging to the most productive group as well) and IBC-Palma 2, are: Catiguá MG 3 and IBC-Palma 2.

Most of the correlations of growth characteristics among each other and between productivity were significant, as observed in Table 3. Similar results were found by Carvalho et al. (2010), when evaluating the growth characteristics of coffee trees in the initial stages of development and to determine their correlations with the first productivity of crops grown in different environments.

Regarding the productivity of cultivars and progenies of arabica coffee, under drip irrigation conditions in the 2018 crop, it can be seen, observing Figure 7, that it was significant, by the analysis of variance, at the 1\% probability level of error. The average yield of the treatments, for this crop was $19.55 \mathrm{sc} \mathrm{ha}^{-1}$. According to CONAB (2018), the average yield of Arabica coffee in Goiás in the 2018 harvest, a year of positive biennial, reached $33.09 \mathrm{sc} \mathrm{ha}^{-1}$ in irrigated crops. 
In the group with higher productivity were the genotypes: Catiguá MG 1, Acauã Novo, Acauã 2 and 8, Catucaí Amarelo 24/137, Catucaí Amarelo 2SL, Asa Branca, Paraiso H 419-10-6-2-10-1, Catuaí Vermelho IAC 15, Acauã, Sarchimor MG 8840, IPR 98, Araponga MG 1 and Obatã Vermelho IAC 1669-20. The productivity of these genotypes varied between 21.92 and $36.61 \mathrm{sc} \mathrm{ha}^{-1}$. They are genotypes of low size, for the most part, however, Catucaí Amarelo 2 SL belongs also to the group of the highest averages of plant height. Low-sized plants facilitate handling with crop and harvest.

Of the thirteen most productive genotypes, two cultivars obtained a productivity higher than this state average, in the 2018 crop, Araponga MG 1, with $36.3 \mathrm{sc} \mathrm{ha}^{-1}$ and Obatã Vermelho IAC 1669-20, with $36.61 \mathrm{sc} \mathrm{ha}^{-1}$ (approximately 10.6\% more, productivity). The genotype IPR $98\left(33.0 \mathrm{sc} \mathrm{ha}^{-1}\right)$ was in the state average. It then shows the potential for adaptation of some genotypes to planting in this region.

Carvalho et al. (2005), studying the agronomic performance of coffee cultivars in the state of Minas Gerais, found that in Turmalina, Catucaí Amarelo 2SL and Obatã Vermelho IAC 1669-20 were in the group with higher productivity, considering a general average of four harvests. Carvalho et al. (2017) found that in the municipalities of Lavras and Patrocínio, among three groups, Araponga MG 1 was in the less productive group, considering an average of productivity in the 2011/2012 and 2012/2013 harvests.

The group of those that presented average productivity, were nine cultivars [Paraíso MG 419-1, Catiguá MG 3, IPR 104, Tupi IAC 1669-33, Catuaí Amarelo IAC 062, IPR 99, IPR 100, IPR 103, Catucaí Amarelo 20/15 cave 479, Sabiá Tardio or Sabiá 398] and three advanced progenies [23II, H-419-3-3-7-16-4-1 and Paradise H 419-10-6-2-12-1]. Their average ranged between 15.2 and 20.6 bags of coffee benefited per hectare.

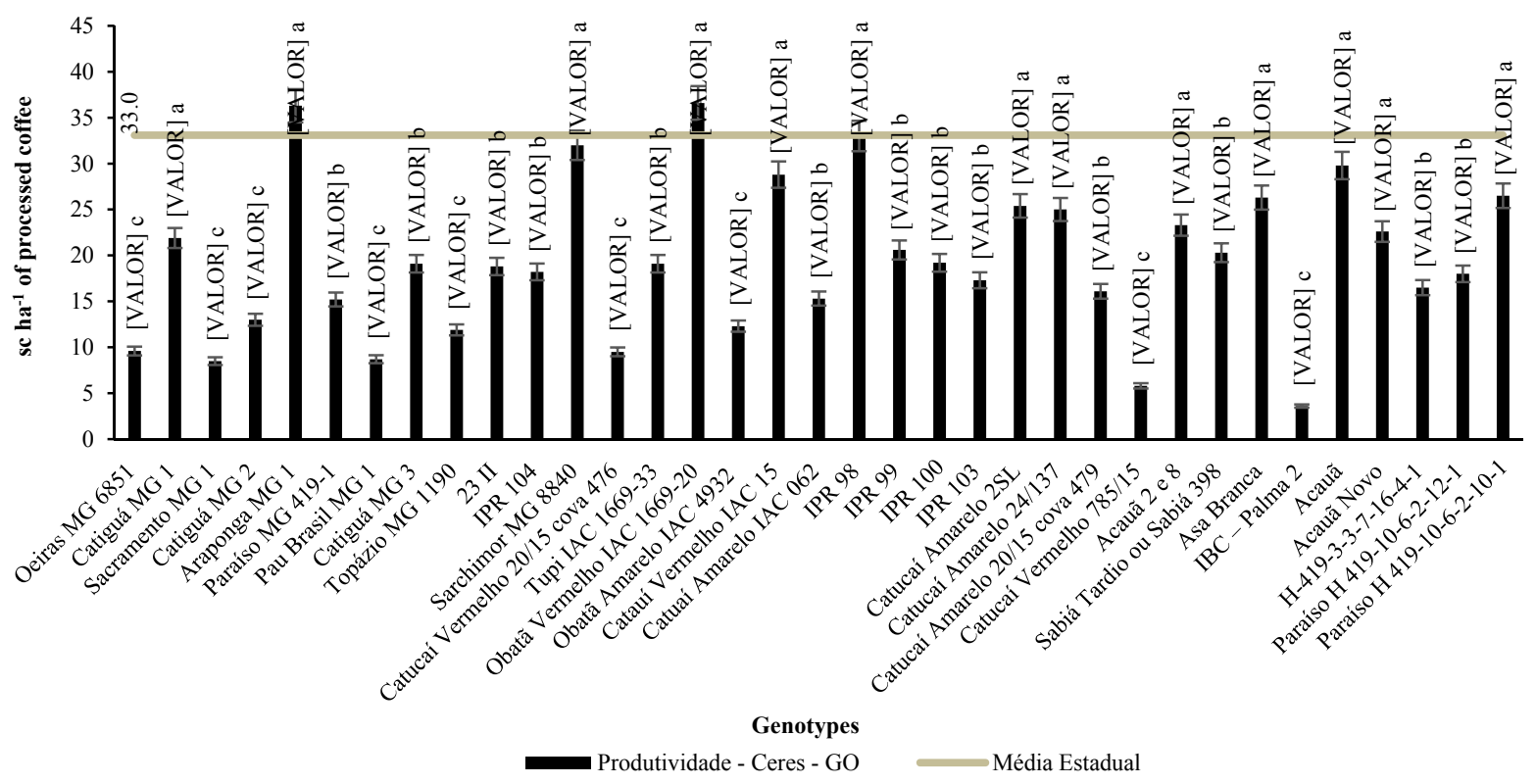

Figure 7. Productivity of coffee benefited

Note. Productivity of coffee benefited (60 kg/ha) of 35 genotypes of Coffea arabica, compared to the average state of Goiás, in the 2018 harvest.

Among the 35 recommended genotypes, Oeiras MG 6851, Sacramento MG 1, Catiguá MG 2, Pau MG Brasil 1, Topázio MG 1190, Catucaí Vermelho 20/15 cova 476, Obatã Amarelo IAC 4932, Catucaí Vermelho 785/15, IBC-Palma 2 The productivity of coffee bags benefited from $60 \mathrm{~kg}$ of coffee ranged from 3.6 to $13.0 \mathrm{bags}$ of coffee benefited per hectare. The IBC-Palma 2 was the least productive genotype, being therefore the least indicated for these growing conditions, because it is only a little.

\section{Conclusions}

There was a difference in growth and yield of the evaluated genotypes.

There is a positive correlation between the vegetative characters and between them and the productivity, in the second crop, of coffee. 
Catucaí Amarelo 2SL presented higher growth than the other evaluated genotypes.

The genotypes Catiguá MG 1, Acauã Novo, Acauã 2 and 8, Catucaí Amarelo 24/137, Catucaí Amarelo 2SL, Asa Branca, Paraíso H 419-10-6-2-10-1, Catuaí Vermelho IAC 15, Acauã, Sarchimor MG 8840, IPR 98, Araponga MG 1 and Obatã Vermelho IAC 1669-20 were the ones that had the highest productivity in the year 2018.

\section{Acknowledgements}

The authors are grateful to the Goian Federal Institute-Campus Ceres for the support given to the Research Support Foundation of the State of Goiás-FAPEG for the research assistance in the implementation of the experiment, to the National Council for Research and Scientific and Technological Development-CNPq, and Dr. Antônio Alves Pereira (Agricultural Research Company of the State of Minas Gerais-EPAMIG) for the supply of seeds of the coffee genotypes.

\section{References}

Aerts, R., Geeraet, L., Berecha, G., Hundera, K., Muys, B., Kort, H. D., \& Honnay, O. (2017). Conserving wild Arabica coffee: Emerging threats and opportunities. Agriculture, Ecosystems and Environment, 237, 75-79. https://doi.org/10.1016/j.agee.2016.12.023

Allen, R. G., Pereira, L. S., Raes, D., \& Smith, M. (1998). Crop evapotranspiration: Guidelines for computing crop water requirements. FAO Irrigation and Drainage Paper 56 (p. 300). Rome: FAO. https://doi.org/ 10.4236/jacen.2014.32B010

Assis, G. A., Silva, L. R. S., Martins, W. E. R., Carvalho, F. J., \& Pires, O. S. (2018). Coffee plant growth and produtivity in Alto Paranaíba region based on punning type and on thinning. Ciência Agrícola, 16(2), 9-21, 2018. https://doi.org/10.28998/rca.v16i2.4467

Carvalho, A. M., Cardoso, D. A., Carvalho, G. R., Carvalho, V. L., Pereira, A. A., Ferreira, A. D., \& Carneiro, L. F. (2017). Behavior of coffee cultivars under the incidence of diseases of rust and gray leaf spot in two cultivation environments. Coffee Science, 12(1), 100-107. https://doi.org/10.25186/cs.v12i1.1248

Carvalho, A. M., Mendes, A. N. G., Botelho, C. E., Oliveira, A. C. B., Rezende, J. C., \& Rezende, R. M. (2012). Agronomic performance of coffee cultivars resistant to coffee rust in Minas Gerais State, Brazil. Bragantia, 71(4), 481-487. https://doi.org/10.1590/S0006-87052013005000007

Carvalho, A. M., Mendes, A. N. G., Carvalho, G. R., Botelho, C. E., Gonçalves, F. M. A., \& Ferreira, A. D. (2010). Correlation between growth and yield of coffee cultivars in different regions of the state of Minas Gerais, Brazil. Pesquisa Agropecuária Brasileira, 45(3), 269-275. https://doi.org/10.1590/s0100-204x2010 000300006

Castanheira, D. T., Rezende, T. T., Baliza, D. P., Guedes, J. M., Carvalho, S. P., Guimarães, R. J., \& Viana, M. J. R. (2016). Potential use of anatomical and physiological characteristics in the selection of coffee progênies. Coffee Science, 11(3), 375-386. https://doi.org/10.5965/223811711732018547

CECAFÉ (Conselho dos Exportadores de Café do Brasil). (2018). Relatório Mensal de Exportações-Dezembro de 2018. Retrieved from https://www.cecafe.com.br/publicacoes/relatorio-de-exportacoes

CONAB (Companhia Nacional de Abastecimento). (2018). Acompanhamento da safra brasileira-Quarto levantamento (Vol. 5, pp. 1-84). Retrieved from https://www.conab.gov.br/info-agro/safras/cafe

Guerra, A. F., Rocha, O. C., Rodrigues, G. C., Sanzonowicz, C., Sampaio, J. B. R., Silva, H. C., \& Araújo, M. C. (2005). Irrigation coffee in the Cerrado: Water management strategy for uniform blossoming (Embrapa Cerrados, Comunicado Técnico, 122, p. 4). Planaltina: Embrapa Cerrados. Retrieved from https://ainfo.cnptia.embrapa.br/digital/bitstream/CPAC-2009/27309/1/comtec_122.pdf

Guimarães, P. T. G., Garcia, A. W. R., Alvarez, V. H., Prezotti, L. C., Viana, A. S., Miguel, A. E., ... Monteiro, A. V. C. (1999). Cafeeiro. In A. C. Ribeiro, P. T. G. Guimarães, \& V. H. Alvarez (Eds.), Recomendações para uso de corretivos fertilizantes em Minas Gerais: $5^{a}$ aproximação (pp. 289-302). Viçosa: CFSEMG. Retrieved from https://www.skoob.com.br/livro/pdf/recomendacoes-para-o-uso-de-corretivos-e/livro:12194 3/edicao:135332

Herrera, J. C., \& Lambot, C. (2017). The Coffee Tree-Genetic Diversity and Origin (Chapter 1, pp. 1-16). In B. Folmer (Ed.), The Craft and Science of Coffee (p. 529). Amsterdam: Academic Press. https://doi.org/ 10.1016/B978-0-12-803520-7.00001-3

ICO (International Coffee Organization). (2018a). Record exports in coffee year 2017/2018. Retrieved from http://www.ico.org/show_news.asp?id=67 
ICO (International Coffee Organization). (2018b). World coffee production reaches 160 million and consumes 159 million bags in coffee year 2017/2018. Retrieved from http://www.ico.org/show_news.asp?id=671

INMET (Instituto Nacional de Meteorologia). (2018). Estações automáticas: Gráficos. Retrieved from http://www.inmet.gov.br/portal/index.php?r=home/page\&page=rede_estacoes_auto_graf

Kitzberger, C. S. G., Scholz, M. B. S., \& Benassi, M. T. (2014). Bioactive compounds content in roasted coffee from traditional and modern Coffea arabica cultivars grown under the same edapho-climatic conditions. Food Research International, 61, 61-66. https://doi.org/10.1016/j.foodres.2014.04.031

Krohling, C. A., Matiello, J. B., Almeida, S. R., Eutrópio, F. T., \& Carvalho, C. H. S. (2017). Adaptation of progenies/cultivars of arabica coffee (Coffea arabica L.) in mountainous edafoclimatic conditions. Coffee Science, 13(2), 198-209. https://doi.org/10.25186/cs.v13i2.1417

Lambot, C., Herrera, J. C., Bertrand, B., Sadeghian, S., Benavides, P., \& Gaitán, A. G. (2017). Cultivating coffee quality: Terroir and agro ecosystem (pp. 17-49). In B. Folmer (Ed.), The craft and science of coffee (p. 529). Academic Press, Amsterdam, Netherlans. https://doi.org/10.1016/B978-0-12-803520-7.00002-5

Oliveira, L. F. C., Oliveira, R. Z., Borges, L. B., \& Wehr, T. R. (2007). Crop coefficient and water relationships of coffee Catucaí cultivar under two systems of irrigation management. Pesquisa Agropecuária Tropical, 37(3), 154-162. https://doi.org/10.5216/pat.v37i3.1855

Rodrigues, W. P., Vieira, H. D., Barbosa, D. H. S. G., \& Vittorazzi, C. (2012). Growth and yield of Coffea arabica L. in Northwest Fluminense: $2^{\text {nd }}$ harvest. Revista Ceres, 59(6), 809-815. https://doi.org/10.1590/ S0034-737X2012000600011

Santos, H. G., Jacomine, P. K. T., Anjos, L. H. C., Oliveira, V. A., Lumbreras, J. F., Coelho, M. R., ... Oliveira, J. B. (2013). Sistema Brasileiro de Classificação de Solos (3rd ed., p. 353). Brasília: Embrapa. Retrieved from https://livimagens.sct.embrapa.br/amostras/00053080.pdf

Vicente, M. R., Mantovani, E. C., Fernandes, A. L. T., Delazari, F. T., \& Figueiredo, E. M. (2015). Effects of different levels of irrigation depth on growth and production variables of coffee under center pivot irrigation. Irriga, 20(3), 528-543. https://doi.org/10.15809/irriga.2015v20n3p528

\section{Copyrights}

Copyright for this article is retained by the author(s), with first publication rights granted to the journal.

This is an open-access article distributed under the terms and conditions of the Creative Commons Attribution license (http://creativecommons.org/licenses/by/4.0/). 